\title{
Nutritional, Phytochemical and Fourier Transform Infra-Red Spectroscopy Profiling of Vernonia amygdalina Seeds
}

\author{
${ }^{1 *}$ Adebayo, O.R., ${ }^{2}$ Efunwole, O.O., ${ }^{1}$ Adegoke, B.M., ${ }^{1}$ Raimi, M.M.and ${ }^{1}$ Adedokun, A.A. \\ ${ }^{1}$ Department of Applied Sciences, Osun Sate Polytechnic Iree. Nigeria \\ ${ }^{2}$ Department of Science Laboratory Technology, Osun State Polytechnic, Iree, .Nigeria \\ *Corresponding author e-mail: adebayo.olukemi70@gmail.com \\ DOI: 10.31364/SCIRJ/v7.i7.2019.P0719669 \\ http://dx.doi.org/10.31364/SCIRJ/v7.i7.2019.P0719669
}

\begin{abstract}
Nutritional composition, phytochemicals and Fourier transforminfra-red spectroscopy profiling of Vernonia amygdalina seeds were investigated using standard procedures. The proximate composition (\%) of the Vernonia amygdalina seeds was found to be; ash (9.828 \pm 0.195$)$, moisture (5.447 \pm 0.070$)$, crude fat (9.480 \pm 0.480$)$, crude fibre (23.124 \pm 0.780$)$, protein ( $25.235 \pm 0.000)$ and carbohydrate contents $(26.886 \pm 0.000)$. The seeds also contains appreciable amount of vitamins $(\mathrm{mg} / \mathrm{g})$; Vitamin C (50.807 \pm 0.832$)$, vitamin $B_{1}(0.096 \pm 0.001)$ and vitamin $B_{2}(0.055 \pm 0.005)$. The mineral content of the sample $(\mathrm{mg} / \mathrm{kg})$ were sodium (30.400), potassium (85.100), calcium (61.200), magnesium (6.185), iron (1.072), zinc (0.311) and manganese (0.273).The phytochemical analyses showed that total phenol, saponins, alkaloid, flavonoids, glycosides and tannins were present while terpenoids and anthraquinones were absent. The results from the infrared spectrum characterize the bioactive compounds present in the Vernonia amygdalina seeds sample. It is advantageous to incorporate Vernonia amygdalina seeds as food supplement for human and livestock benefits.
\end{abstract}

Keywords: Infra-red Spectroscopy, minerals, phytochemicals, seeds, Vernonia amygdalina, vitamins

\section{INTRODUCTION}

Vernonia amygdalina commonly known as bitter leaf is a shrub in the family of Asteraceae ( Ijeh and Ejike, 2011). It is a vegetable used for preparing the popular bitter leaf soup. Although this plant has been around for hundreds of years, only a few people know of its medicinal and healing properties great for diabetic patients (Kokwaro, 2009).Bitter leaf as the name implies, is a plant that is often known for its bitter taste, but underneath that bitterness, are useful and numerous health benefits, that is highly needed by our body. The plant precisely in Nigeria is very a common vegetable that is abundantly grown almost everywhere in the county. It is popularly known as Ewuro amongst the Yorubas, Onugbu by the Igbos and called Shiwaka by the Hausas.

This shrub has been used by traditional locals to treat different ailments and diseases due to the medicinal value and healing potencies present in this vegetable ( Huffman and Seifu, 1989).However the vegetable can be prepared by juicing it with blender, juicer or it can be done in the local way by adding little water to the leaves rubbing it on palm and squeezing the juice out of it. Another way of preparing it is by cooking it as a soup (Bitter leaf soup is a popular delicacy amongst the Southern people of Nigeria). But it works www.scirj.org 
effectively when it's juiced. Vernonia amygdalina has also been fed to broilers, where it was able to replace $300 \mathrm{~g} / \mathrm{kg}$ of maize-based diet without affecting feed intake, body weight gain and feed efficiency (Teguia et al., 1993; Bonsi et al., 1995)

The aim of this study is to investigate the chemical composition, phytochemicals, minerals element and vitamins, and bioactive compounds by means of infra red spectroscopy embedded in Vernonia amygdalina seeds.

\section{MATERIALS AND METHODS}

\section{Sample collection and preparation.}

The Vernonia amygdalina seeds used for this study were procured during the dry season from a garden in Egbedore Local Government Area, Osun State, Nigeria. The seeds sample was air dried at room- temperature for about three weeks, after which it was grinded with mortar and pestle into a fine powdered and sieved with a $1.5 \mathrm{~mm}$ plastic sieve. It was kept in an airtight container for subsequent uses.

\section{Methodology}

\section{Aqueous extraction}

The aqueous extract of the sample was prepared by soaking $100 \mathrm{~g}$ of dried powdered samples in $200 \mathrm{ml}$ of distilled water for 12 - hour. The extracts were filtered using whatman filter paper no 42 (125mm).

\section{Phytochemical analysis}

Chemical tests were carried out on the aqueous extract and on the powdered specimens using standard procedures as to identify the constituents as described by Sofowara (1993), Trease and Evans (1989) and Harborne (1973).

\section{Determination of Vitamin C (Ascorbic acid)}

About $0.5 \mathrm{~g}$ of the sample was weighed, macerated with $10 \mathrm{mls}$ of $0.4 \%$ oxalic acid in a test tube for 10 minutes, centrifuged for 5 minutes and the solution filtered. $1 \mathrm{ml}$ of the filtrate was transferred into a dry test tube in duplicates, $9 \mathrm{mls}$ of 2.6 dichlorophenol indophenols was added and absorbance was taken at 15 seconds and 30 seconds interval at 520nm ( AOAC, 1990).

\section{Determination of Vitamin $B_{1}$ and $B_{2}$}

These vitamins $B_{1}$ and $B_{2}$, were determined by spectrophotometric method as described by Khalil and Mann, (1990).

\section{Fourier Transform Infra-Red Spectroscopy Analysis (FTIR)}


About $2 \mathrm{mg}$ of the sample and $200 \mathrm{mg} \mathrm{KBr}$ was dried and ground. The mixture was squeezed to form transparent pellets which was measured directly (Perkins, 1986).

\section{Proximate and Mineral Analyses}

These were carried out according to the method described by the Association of Official Analytical Chemist (1990).

\section{RESULTS AND DISCUSSION}

Table 1: Proximate Composition of Vernonia amygdalina Seeds

\begin{tabular}{|l|r|}
\hline Parameters & Composition (\%) \\
\hline Ash content & $9.828 \pm 0.195$ \\
Moisture content & $5.447 \pm 0.070$ \\
Crude fat content & $9.480 \pm 0.480$ \\
Crude fibre content & $23.124 \pm 0.780$ \\
Protein. Content & $25.235 \pm 0.000$ \\
Carbohydrate content & $26.886 \pm 0.000$ \\
\hline
\end{tabular}

Table 2: Minerals Composition of Vernonia amygdalina Seeds

\begin{tabular}{|l|r|}
\hline Parameters & Compositions $(\mathrm{mg} / \mathrm{kg})$ \\
\hline Sodium & $30.400 \pm 0.02$ \\
Potassium & $85.100 \pm 0.001$ \\
Calcium & $61.200 \pm 0.004$ \\
Magnesium & $6.185 \pm 0.001$ \\
Iron & $1.072 \pm 0.001$ \\
Zinc & $0.311 \pm 0.003$ \\
Lead & $\mathrm{NA}$ \\
Manganese & $0.273 \pm 0.002$ \\
\hline
\end{tabular}

Key: NA-not detected

www.scirj.org

(C) 2019, Scientific Research Journal

http://dx.doi.org/10.31364/SCIRJ/v7.i7.2019.P0719669 
Table 3: Qualitative Phytochemical Composition of Vernonia amygdalina Seeds

\begin{tabular}{|l|r|}
\hline Parameters & Constituents \\
\hline Tannins & $+\mathrm{ve}$ \\
Total Phenols & $+\mathrm{ve}$ \\
Alkaloids & $+\mathrm{ve}$ \\
Flavonoids & $+\mathrm{ve}$ \\
Terpenoids & $-\mathrm{ve}$ \\
Saponins & $+\mathrm{ve}$ \\
Glycosides & $+\mathrm{ve}$ \\
\hline
\end{tabular}

Key: +ve - presence of constituent -ve - absence of constituent

Table 4: Quantitative Phytochemical Composition of Vernonia amygdalina Seeds

\begin{tabular}{|l|r|}
\hline Parameters & Compositions \\
\hline Total phenols & $12.799 \pm 0.013$ \\
Saponins & $7.037 \pm 0.020$ \\
Alkaloids & $3.756 \pm 0.000$ \\
Flavonoids & $5.996 \pm 0.000$ \\
Glycosides (mg/kg) & $5.060 \pm 0.000$ \\
Tannins (mg/g) & $1.209+0.000$ \\
\hline
\end{tabular}

Tables 5: Vitamin Composition of Vernonia amygdalina Seeds

\begin{tabular}{|l|r|}
\hline Parameters & Compositions $(\mathrm{mg} / \mathrm{g})$ \\
\hline Vitamin C & $50.807 \pm 0.832$ \\
Vitamin $\mathrm{B}_{1}$ & $0.096 \pm 0.001$ \\
Vitamin $\mathrm{B}_{2}$ & $0.055 \pm 0.005$ \\
\hline
\end{tabular}


Table 6: Infrared Vibration Bands and Functional Compounds of Vernonia amygdalina Seeds

\begin{tabular}{|l|r|}
\hline Wave number $\mathrm{cm}^{-1}$ & Functional compounds \\
3395.0 & Alkanes with strong intensity nitriles, thiols, methylene group. \\
2925.37 & $\mathrm{C}=$ O Strong intensity saturated aldehyde \\
1727.67 & $\mathrm{C}-\mathrm{OH}=\mathrm{C}$ alkene \\
1429.00 & Bending vibration; COOH carboxylic group \\
1377.00 & Aromatics, phenyl group OH - \\
1257.25 & Amines, esters, P - OR esters. \\
1038.36 & Phosphate (str). \\
\hline
\end{tabular}

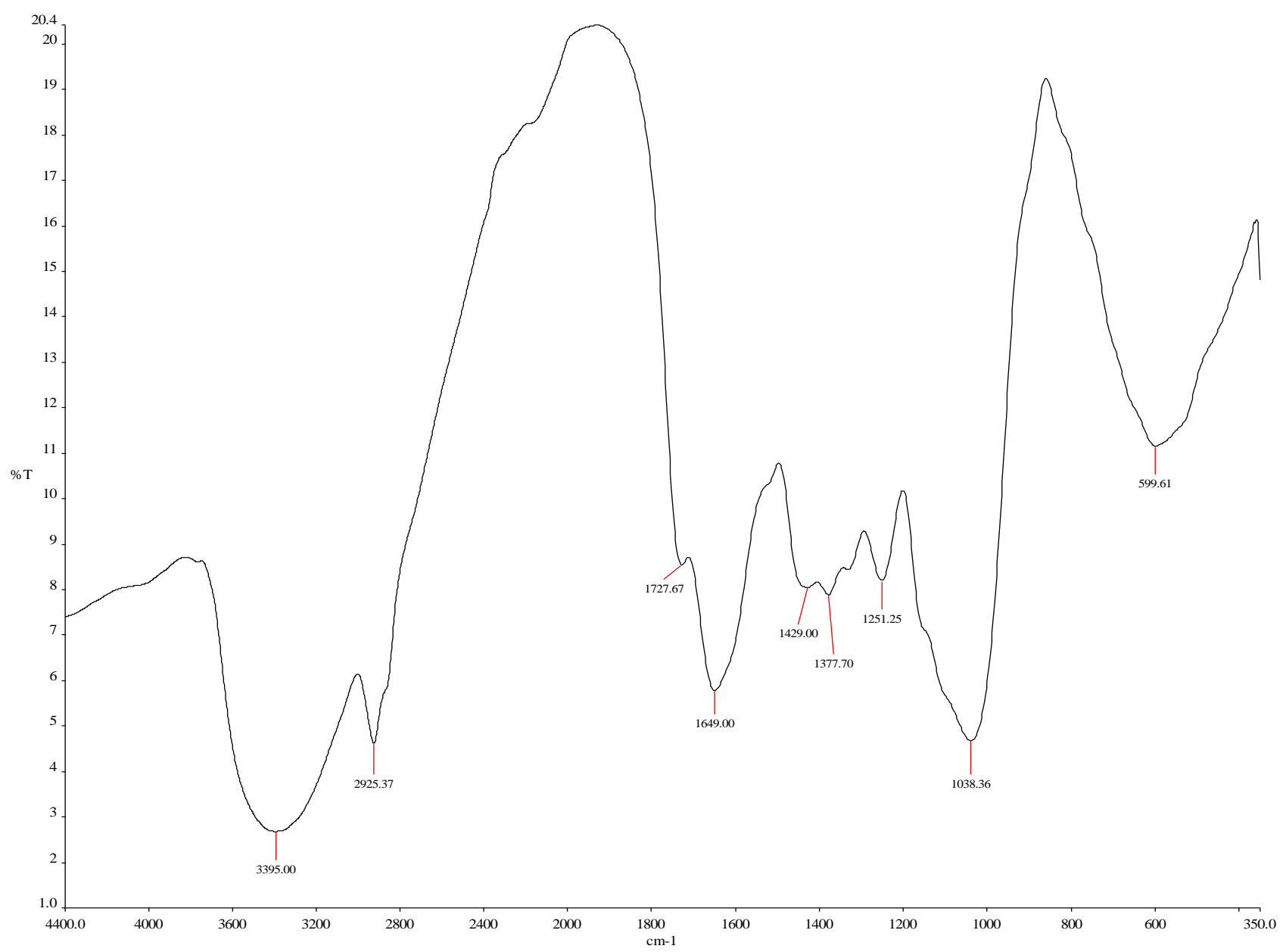

Fig 1: Infrared spectrum of Vernonia amygdalina seeds extracts using Fourier Transform Infra-red spectroscopy

Www.scirj.org

(C) 2019, Scientific Research Journal

http://dx.doi.org/10.31364/SCIRJ/v7.i7.2019.P0719669 
The proximate compositions $(\%)$ of Vernonia amygdalina seeds were shown in table 1 . The nutrient in food is of great importance, has it accounts for the establishment of nutritional composition. The Vernonia amygdalina seeds showed a higher value of ash content $(9.828 \pm 0.195 \%)$ when compared with water melon seeds (6.000 \pm 0.10$)$. This is an indication of higher mineral contents (Anwar et al., 2008). The crude fat content of the Vernonia amygdalina seeds is $(9.480 \pm 0.480 \%)$ while the value is lower when compared with that of bitter lemon seeds which is $(34.00 \pm 0.00)$ as reported by Matthew et al., (2014).Healthwise, fat plays a vital role in hair and skin, which insulate the body organs against shock, maintaining body temperature and promoting healthy cell function. It is also essential in enhancing the diets as they increase the pleasant taste of food (Omotoso, 2006). But Vernonia amygdalina seeds cannot be regarded as oil seeds. The result shows that Vernonia amygdalina seeds have a higher value of crude fibre $(23.124 \pm 0.780 \%)$ than that of Citrus maxima peels $(2.58 \pm 0.41)$ as reported by Peace and Happiness, (2018). The physiological role of crude fibre in the body is to maintain an internal distention for poor peristaltic movement of the intestinal tract (Oduor et al., 2008). The protein content in the Vernonia amygdalina seeds is $(25.235 \pm 0.000 \%)$ when compared with watermelon seeds content (21.500 \pm 0.13$)$ as reported by Matthew et al., (2014). The high protein content in the sample showed that it could be regarded as good source of protein; hence it can be modified into protein concentrate feeds for livestock. The higher level of protein in the samples indicates that it contributes significantly to the daily protein requirements of 23 - 56g for humans as stipulated by the NRC (1980).The carbohydrate value of the sample is $26.886 \pm 0.000 \%$ thus it is rich in energy that is also good for the body.

The mineral element of the sample is shown in table 2 . The level of sodium in the sample is $30.400 \pm 0.02$. This value is compared with the value obtained for Citrus maxima peels (274.77 \pm 5.07$)$ as reported by Peace and Happiness (2018). Sodium helps in maintaining body fluid. The value obtained for potassium in the sample is $85.100 \pm 0.001$ and high when compared with that reported by

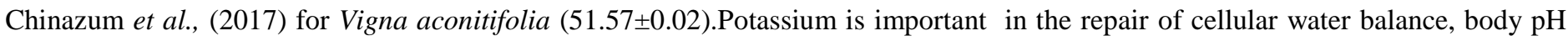
regulation and also associated with carbohydrate and protein metabolism (Shils,1973). According to Shils (1973), more intake of potassium can reduce blood pressure up to $3.2 \mathrm{mmHg}$ value, which implies that it can reduce death rate to about $8 \%$.The calcium content of the sample is $(61.200 \pm 0.004)$, which is higher than the value obtained from pawpaw seeds $(5.46 \pm 0.03)$ as reported by Matthew et al., (2014).Calcium is a structural component of bones and teeth. It also plays a vital role in enzyme activation, blood clotting, muscle contraction and cellular processes (Gropper et al., 2005).Magnesium content in the sample is $6.185 \pm 0.001$ which is higher than 3.21 \pm 0.12 for cherry seeds as reported by Matthew et al., (2014). Magnesium is an enzyme activator in biochemical and physiological processes (Schrauzer, 2000).Iron in seeds is necessary in formation of haemoglobin and normal functioning of the central nervous system. There is no much difference in iron ofVernonia amygdalina seeds (1.072 \pm 0.001$)$ and that of Vigna aconitifolia seeds (1.490 \pm 0.00$)$. Iron increases the amount of blood in human especially in anaemic conditions and also it is necessary for cognitive growth, proper functioning of the immune system, energy metabolism and temperature regulation ( Baynes, 2000). The WWW.scirj.org 
zinc content of the Vernonia amygdalina seeds is lower $(0.311 \pm 0.003)$ to that of the zinc content in water melon seeds $(5.52 \pm 0.20)$ as reported by Matthew et al., (2014). Zinc is important for the regulation of many biochemical processes and physiological functions of living tissues (Berry, 1998). The manganese content of Vernonia amygdalina seeds is $0.273 \pm 0.002$. Manganese helps in metabolism of carbohydrates and proteins. It is also essential for proper brain function as well as strengthening of weak bones and painful joints (Franklin, 2000).

The results reveal the presence and absence of some certain phytochemicals in tables 3 and 4. Phenol is important in reducing risk of heart disease by controlling cholesterol accumulation (Meyer et al.,1997).Phenolics in functional food have antioxidant effect and its mechanism involves free radical scavenging and metal chelating activities (Wang et al., 2014). Saponins helps to reduce cancer risk as anti - oxidant, reduce bone loss and immunity booster (Sodipo et al., 2000). Saponins has relationship with sex hormones like oxytocin. Oxytocin is a sex hormone involved in controlling the onset of labour in women and the subsequent release of milk (Sodipo et al., 2000). Alkaloids are secondary plant metabolite with great pharmacological significance (Adeolu and Enesi, 2013 ). Flavonoids in the plant is rich and it has the potency to minimize inflammation in the arteries. It also guides the body's cell from dangerous free radicals that comes from smoke and other environmental contaminant (Maria et al., 2009).Tannins are involved in healing wounds and inflamed mucus membrane. They also exhibit astringent and antimicrobial potentials (Braids et al., 2012).

The vitamins compositions of Vernonia amygdalina seeds were shown in table 5.Vitamin C also known as ascorbic acid is an enzyme co-factor required for synthesis of important biochemicals (Hunt et al., 1980). Vitamin C is also a potent antioxidant which reduces oxidative stress. It is required for maintenance of normal connective tissue and involved in wound healing (Chaney, 2006). Its deficiency results to capillary fragility, scurvy and anemia (Chaney, 2006). Among the investigated vitamins, vitamins C had the highest concentration. The content of vitamin $\mathrm{C}$ in Vernonia amygdalina seeds is $50.807 \pm 0.832$ and higher than the content in Moth bean seeds (42.250 \pm 0.010$)$. The availability of vitamin C in Vernonia amygdalina seeds suggest that its of high capacity and plays a mediated roles in fighting against germs in the body. Vitamins B complexes are classified as energy releasing water soluble vitamins, they are very essential for regulation of normal human metabolism especially in minutes measure. Vitamin $\mathrm{B}_{1}$ is also known as thiamine and the value of Vitamin $\mathrm{B}_{1}$ content in Vernonia amygdalina seeds is $(0.096 \pm 0.001)$ lower than the content in Moth bean (0.239 \pm 0.000$)$. The deficiency of vitamin $\mathrm{B}_{1}$ causes the disease known as beriberi (Hunt et al., 1980). Vitamin $\mathrm{B}_{2}$ also known as riboflavin. The content of $\mathrm{B}_{2}$ in Vernonia amygdalina seeds $(0.055 \pm 0.005)$ is lower than Moth beans $(0.450 \pm 0.000)$. Deficiency of riboflavin does not result to a specific disease; however there is the possibility of underestimating its importance. The symptoms of riboflavin deficiency include inflammation of the tongue, and lesions in the eyes and lips (Hunts et al., 1980; Tayor, 1972). Vitamin 
B complexes help the body produce the energy it needs to function better. It also assists the body in the formation of red blood cells which supply oxygen to the body tissues (Hunts et al., 1980) and Tayor, 1972).

Table 6 depicts the infrared spectrum of Vernonia amygdalina seeds. The result of the infrared spectrum showed that the functional group region which ranges from $4000-1450 \mathrm{~cm}-1$ which usually contained relatively few peaks associated with stretching vibrations. Absorptions peak $3395 \mathrm{~cm}-1$ is characterized with OH (hydroxyl) functional group, $2925.37 \mathrm{~cm}-1$ showed an alkanes having strong intensity with $\mathrm{CH}_{3}, \mathrm{CH}_{2}$ and $\mathrm{CH}$, nitriles, thiols and methlene group. However, absorption at $1727.67 \mathrm{~cm}-1$ showed a saturated carbonyl compounds having strong intensity. Also the absorption at $1649.00 \mathrm{~cm}-1$ indicated the presence of a carbon - carbon double bond $(\mathrm{C}=\mathrm{C})$; an alkene group. The peak at $3395 \mathrm{~cm}-1$ has already been attributed to hydroxyl $\left(\mathrm{OH}^{-}\right)$group. This confirms the presence of large amount of saponin compound in Vernonia amygdalina seeds. Compounds such as alkaloids, saponins, tannins and flavonoids have been reported to have inhibitory properties (Uyoh et al., 2013). Thoils functional group at the peak $2925.37 \mathrm{~cm}^{-1} 1$ are group of thiopheres which are organo - sulphur, heterocyclic compound also known as thio furan having potential therapeutic in the treatment of ailments. However, at the finger print region, ranging from $1450-400 \mathrm{~cm}^{-1} 1$ characterized with bending vibration within the molecule. This region is important because each different compound produces its own unique pattern of peaks as shown in the infrared spectrum in figure 1. At this finger print region, peak at $1429 \mathrm{~cm}^{-1} 1$ showed carl on bonded for hydroxyl group $(\mathrm{C}-\mathrm{OH})$; carboxylic group absorption at $1377 \mathrm{~cm}^{-1} 1$ depicts the presence of aromatics phenyl group. Phosphate group at $1251.25 \mathrm{~cm}^{-1} 1$ having strong intensity. In addition, the absorption at $1038.36 \mathrm{~cm}^{-1} 1$ showed the presence of amines and esters. The carboxylic group of acetohydroxamic acid is one of the inhibitors studied as the potential therapeutic drug in the treatment of ulcer caused by Helicobacter pylori and has been suggested as a means of preventing the various related pathological conditions (NBMC, 2017). Also the presence of hydrogen atom attached to the carbon $(\mathrm{C}-\mathrm{H})$ in the ring by a substituent group $\left(\mathrm{OH}, \mathrm{NH}_{2}, \mathrm{NH}, \mathrm{COOH}\right)$ improves inhibition (Debi et al., 2013). The natural phenolic compound is important due to the health benefits it confers to the body (Gil et al., 2002). The presence of phenols; an aromatic compound in the Vernonia amygdalina seeds conferred medicinal property on the plant's seeds. Phenols and flavonoids are primary antioxidants due to their hydroxyl group $\left(\mathrm{OH}^{-}\right)$directly bonded to the benzene ring. Thus allowing them to easily donate electron to electron deficient free radicals in order to reduce their menace in biological system (Uyoh et al., 2013). .Moreover, esters are traditionally formed from the esterification of alcohol with fatty acids (Vans Der Slius et al., 2002).The significance of ester contribution to development of aroma in well-known short chain esters are highly volatile precursors. Amines have also been found to be flavor precursors and hence the associated flavor with Vernonia amygdalina seeds (Smith, 1982). However, the presence of phosphorus in the form of phosphonate and P-OR esters in the extract of Vernonia seeds depict the medicinal importance of the seeds under investigation. Phosphorus is commonly found in the body as phosphate and it is primary essential minerals for growth and repair of worn - out cells and tissue. According to the University of Maryland Medical Centre, all 
body cell contained about $85 \%$ phosphorus occurring in bones and teeth. The ratio of calcium - phosphorus enhances bone formation and is required for variety of biochemical processes including energy production and pH regulation for a balanced body metabolism (Gropper et al., 2005).

\section{CONCLUSION}

Vernonia amygdalina possesses various bioactivities with low or absence of side effects. With its great health promotion effect, it may be more advantageous to incorporate Vernonia amygdalina seeds into health supplement for human benefits rather than using it solely as feed for the poultry industry. Vernonia amygdalina seeds have been promising boosting immunity and preventing infections. In general, the regular consumption of prebiotics enhanced immune functioning; it improved colonic integrity, decreased incidence and duration of intestinal infections, and improved digestion.

\section{REFERENCES}

Adeolu, A.T.and Enesi,D.O. (2013). Assessment of proximate, mineral, vitamin andphytochemical composition of plaintain (Musa paradisiaca) bract an agricultural waste intl., Res. j. Plant Sci., 4; 192- 197

Anwar, F., Rehana, N., Bhanger, M. I., Ashfat, S., Farah, N. T.and Felix,A. (2008). Physicochemical characteristic of citrus seeds as seed oils from Pakistan. Journal of American oil Chemist Society, 7(2), 112-119

A.O.A.C. (1990). Official Methods of Analysis. Association of Official Analytical Chemists. $15^{\text {th }}$ Edition Washington, D.C.

Baynes, R.D. (2000).Iron in M.Stipanuk (Ed.). H. Biochemical and Physiological aspects of human . Philadelphia: W,B Saunder

Berry, T. N. (1998). The role of condensed tannins in the nutritional value. BrJ. Nutri. 51:493- 504

Bonsi, E. O.and Odoemela,R. (1995). Taste and intake of bitter leaves.

Braide,W. Odiong, I. J. and Oranusi, S. (2012). Phytochemical and Antibacterial properties of the seed of water melon (Citrullus lanatus). Prime J. Of microbio. Res., 2(3):99-104

Chaney, S. G. (2006) Principles of nutrition II; Micronutrient. In; Textbook of Biochemistry with clinical correlations. Delvin Tm(Ed) wiley-liss; Hoboken, N. J. New York NY:

Chinazum, I.O. Anthony, C.C.and Chiemeziem, A.O. (2017). Assessment of proximate, vitamins, mineral and anti-nutrient composition of unprocessed Vigna aconitifolia (Moth beans) seeds. Archives of Current Research International, 11 (2):1-7

Debi, G. E. Esah, A. Mohammed, I. Abdulraham, A. S. and Aminu, M. (2013). Inhibition action of Vernonia amygdalina in the corrosion. Australian Journal of Basic \& Applied Sciences, 7:257-263.

Frankin, P.A (2000).Nature's prescription, Foods, vitamins and supplement that prevent diseases . $6^{\text {th }}$ Edition Pp313-314

Gil, M. I. Tomas, F. A.Barberan,B.Hess-Pie and Kader, A. A. (2002). Antioxidant capacities, phenolic compounds, carotenoids and vitamin C content of nectarine peach and plum cultivars from California. Journal of Agric Food Chem, 50:4976-4982.

Gropper, S. S. Smith, J. L. and Groff, J. M. (2005). Advanced nutrition and human metabolism. $4^{\text {th }}$ ed. Pp. 101-105.USA Wardsworth group.

Harold, R. (1999). Generic and subtribal classification of American Vernonia. Smithsonian contribution to Botany.

WWW.scirj.org

(C) 2019, Scientific Research Journal

http://dx.doi.org/10.31364/SCIRJ/v7.i7.2019.P0719669 
Harborne, J.B. (1973). Phytochemical methods, London chapman and Hall, Ltd Pp 49-188

Huffman, M.A.and Seifu, M. (1989).Observation on the illness and consumption of a possibly medicinal plant Vernonia amygdalina (Dei) by a wild chimpanzee in the Mahale mountain National park Tanzania primates 30:51-63.doi:10.1007/Bf 02381210

Hunt, S. Grott, J. L. and Holbrook, J. (1980). Nutrient principles and chemical practices. John Wiley and sons New York.

Ijeh, II.and Ejike,CECC. (2011). Current perspectives on the medicinal potential of Vernonia amygdalina Dei. J. med. Plant Reg. 5 (7): 1051-1061.

Khalil, I.W. and Mann, F. (1990).Colorimetry and flame photometry. In Chemistry (2 ${ }^{\text {nd }}$ edition0. Taj printing Press, Peshawar, Pakistan. 131-157

Kokwaro, J.(2009). Medicinal plants of East Africa $3^{\text {rd }}$ Edition Nairobi, Kenya: University of Nairobi press.

Matthew, T.J. Ndamitso, M.M. Otori, A. A. Shaba, E. Y. Inobeme, A. and Adamu, A. (2014).Proximate and mineral composition of seeds of some convectional and non-convectional fruits in Niger State, Nigeria. Academic research International. vol. 5 (2)

Maria, M., Nasiruruddin, K., Cristina, A., Rosa, C., Mireia, U. and Rafael, L. (2009). Effect of cocoa powder on the modulation of inflammatory biomarker inpatients at high risk of cardiovascular disease.American Journal of Clinical nutrition, 90:1144-1150

Meyer, A., Yi, O., Pearson, D., Waterhouse , A.L. and Frankel, E. (1997). Inhibition of human low -density lipoprotein oxidation in relation to phenolic antioxidant in grapes. Journal of Agriculture and Food Chemistry .43. 1638-1643.

NBMC (2017).National Biter Melon Council, http://www.bitermelon.org/pages/learn/aboutreference html.

NRC (National Research Council) (1980). Recommended Dietary Allowances. (9 ${ }^{\text {th }}$ Ed.). Nat. Acad. Sci. Washington DC.

Odour, P.M., Struszczyk, M. H. and Peter, M. G.(2008).Characterization of chitosan from Blowfly Larvae and some crustacean species from Kenyan marine waters prepared under different conditions. Discovery and Innovation. 20 (2). 129-142

Okwu, D. E.and Okwu, M. E. (2004). Chemical Composition of Spondia mombim plants. J. Sustain Agric. Environ. 6:140-147.

Omotoso, O.T. (2006). Nutritional quality, functional properties and anti nutrientscompositions of larva of Cirina forda (Westwood Lepidoptera: atuniidae).J. Zhejiang Univ. Sci. B., 7.51-55

Perkins, W.D. (1986).Fourier Transform - Infrared Spectroscopy”. Part 1. Instrumentation. Topics in Chemical Instrumentation. Ed. Frank A. Settle, Jr. Journal of Chemical Education 63:1, January 1986; A5-A10

Peace, N.A. and Happiness, C.A. (2018). Nutrient, phytochemical and anti-nutrient composition of Citrus maxima fruit juice and peel extract. Journal of Food Science and Nutrition

Schrauzer,G. (2000). Selenomethionine : A review of its nutritional significance, metabolism and toxicity. Journal of Nutrition, 130(1653), 2000.

Shils, M.E.(1973). Magnesium in modern nutrition, in wealth and disease. Hart R.S. amd M.E Shils (Eds). Ch 6. Sect. B. Philadelphia

Smith, I. F. (1982). Leafy Vegetables as sources of minerals in Southern Nigeria diets. Nutrition reports Int., 26(4):679-688.

Sodipo,O. A. Akiniyi,J. A. and Ogunbamosu,J. U. (2000).Studies on certain characteristics of extracts of bark of pausinystalia Johimbe and pausinystalia macroceras (K Schum) Pierre ex Beille. Global. J. Pure Applied Sci., 6:83-87

Sofowara, A. (1993).Medicinal plants and traditional medicine in Africa. Spectrum Books.Nigeria. $2^{\text {nd }}$ Ed. Pp.10-158

Trease, G.E. andEvans, W.G. (1989). Pharmacogonsy, $11^{\text {th }}$ edition Brailliar Tridal can, Macmillian Publisher

Tayor, O. Y. (1972). Micro nutrients. A Unilever Educational Booklet, Unilever international company, London.

Teguia, A., Choumboue, J.T., Mayaka, B.T.and Tnakou, C.M.(1993).The growthof broiler chickens as affected by the replacement of graded levels of maize by sweet potatoes leaves (Ipomoea batatas) or Ndole (Vernonia spp) in the finisher diet.Anim.feed Sci.Technol.40,Pp.233-237. 
Uyoh, E. A.Chukwura, P. N.David, I. A. and Bassey,A. C. (2013).Evaluation of antioxidant capacity of two Ocimum species consumed locally as spices in Nigeria as a justification for increased domestication. American Journal of Plant Science, 4:222230 .

Van - Der Sluis, A. A., Dekker, M., Skreda, G. and Jongen, N. M. (2002).Activity and concentration of polyphenolic antioxidant in apple juice, effect of existing production methods. Journal of Agric Food Chem. 50(251):7211-7219.

Wang, L. Wang, J. Frang, L., Zheng, Z. Dexian, Z. Wang, S. and Zhao, H. (2014).Anticancer activities of citrus peel polymethoxyflavones related to angiogenesis and other. BioMed Research. International. 453972, https //doi.org $/ 101155 / 2014 / 453972$ 